\title{
Books
}

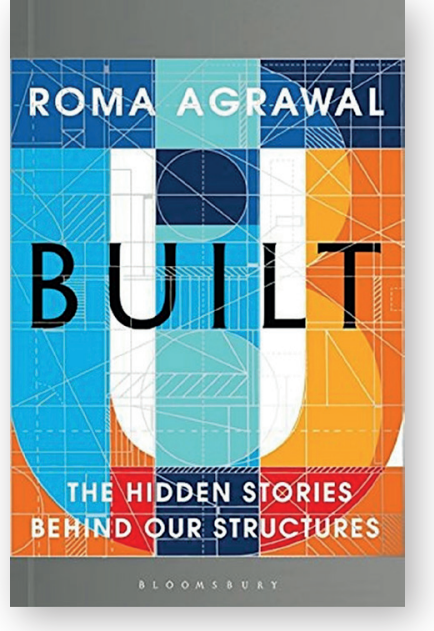

Built: the hidden stories behind our structures

by Roma Agrawal, published by Bloomsbury, 2018, £16.80, reviewed by Veronica Flint Williams, Environment Agency, UK

Roma Agrawal is a great storyteller. I enjoyed the breadth of engineering she covered in this book and also the depth of learning from its historical context. After quoting from Isaac Newton that, 'we are standing on the shoulders of giants,' she provides plenty of examples of how we have built on the understanding of Roman and other civilisations to get to the structures of today.

The book's easy style and compelling storytelling make it suitable for anyone wishing to understand the world of engineering. Non-engineers wishing to understand our world and the built environment we all live in will have their eyes opened.

I would particularly recommend this book to students who wish to pursue a career in engineering. I have noticed many young people attending interviews today lack the language of engineering and the ability to bring engineering into their interview conversations - this book will be of great help to them.

Overall, Built is an enjoyable and inspiring read. My review copy is going to a young friend to help her choose a career in engineering.

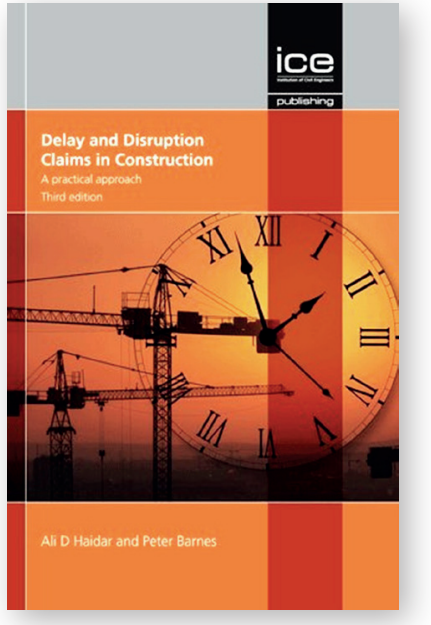

Delay and disruption claims in construction (3rd ed.)

by Ali Haidar and Peter Barnes, published by ICE Publishing, 2017, £55, reviewed by Veronica Flint Williams, Environment Agency, UK

It was a joy to read this book, which I have to admit I managed in one sitting. It clearly explains the basis of the law in relation to claims for delays and disruption, and the requirements of different forms of contract for a valid claim. Helpfully, it links this to relevant case law.

The authors detail the criteria for evaluation and assessment of claims. They present the basis for positive presentation of arguments and evidence most likely to deliver acceptance. The book includes model answers for presenting claims and ordering the evidence in a logical way to lead the reader (or assessor) in an effective way to a logical conclusion.

I would recommend this book to all construction professionals, both those starting their career and also experienced individuals. This includes those in a commercial role, but also anyone undertaking a role with a commercial implication - which would be most of us.

Truly it would be a great efficiency in our sector if the subject area was better understood, such that poorly presented or spurious claims were avoided and well-presented and justified claims were promptly settled.

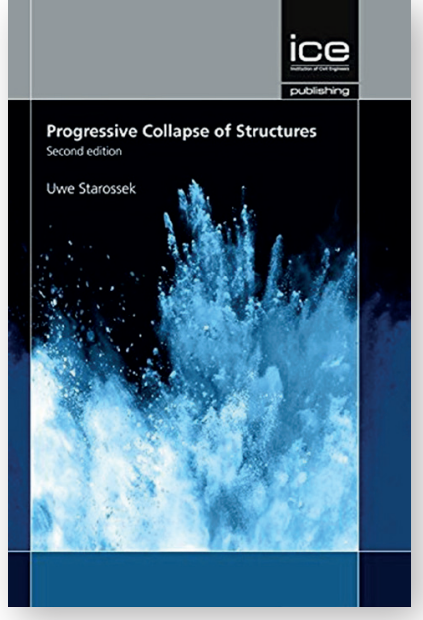

\section{Progressive collapse of} structures (2nd ed.)

by Uwe Starossek, published by ICE Publishing, 2018, f70, reviewed by Philippe Bouillard, Université Libre de Bruxelles, Belgium

This is the second edition of Uwe Starossek's book on progressive collapse of structures. Like the first edition, the book elucidates very clearly and thoroughly the essential notions related to progressive and disproportionate collapse.

It opens with a very clear and large description of progressive collapse typologies, which will definitely open the reader's mind on such possible failures. After a short demonstration of the inadequacy of the ordinary design procedures, Starossek presents the principles for designing against disproportionate collapse and introduces the design method concepts on a few applications.

A very positive aspect of the book is that it is not limited to buildings but presents the concepts for any structures. In the second edition, the author adds two chapters perfectly aligned with the philosophy of the book giving an overview of current codes or guidance documents (UFC, GSA, Eurocode and ASCE) and very clear and detailed guidelines which could serve as guidance. 


\section{MONITOR Books}

The book is definitely a very valuable tool for design engineers, researchers or anyone interested in progressive collapse concepts. To be comprehensive, as claimed by the author, it should however give detailed methods and data so that examples could be reproduced or tested. From a research perspective, the author misses important recent contributions to give a fair overview and accurate advice on possible design and verification methods.

\section{NEW BOOKS}

The ICE Library maintains one of the most comprehensive collections of civil engineering books in the world, including all titles from ICE Publishing (shown in bold below). New books received in the past 3 months include the following.

\begin{tabular}{|c|c|c|}
\hline 101 things I learned in engineering school & J Kuprenas and M Frederick & f8.64 \\
\hline Analysis of engineering structures and material behavior & J Brnic & f99.95 \\
\hline Bridges: a history of the world's most spectacular spans (new ed.) & J Dupre & $f 20 \cdot 00$ \\
\hline Buckling and post-buckling structures II: experimental, analytical and numerical studies & M Aliabadi & $£ 139 \cdot 00$ \\
\hline Building governance and climate change: regulation and related policies & R Lorch et al. & f115.00 \\
\hline Building regulations pocket book & R Tricker and S Alford & f19.99 \\
\hline Coastal engineering ( $3 \mathrm{rd}$ ed.) & D Reeve & $£ 45 \cdot 00$ \\
\hline Contractual procedures in the construction industry (7th ed.) & A Ashworth & $f 45.99$ \\
\hline Development of ultra-high performance concrete against blasts: from materials to structures & C Wu et al. & $£ 170 \cdot 00$ \\
\hline Engineering in perspective: lessons for a successful career & T Ridley & $\mathrm{f} 36 \cdot 00$ \\
\hline Fatigue design of steel and composite structures ( 2 nd ed.) & ECCS & f50. \\
\hline Guide to good practice in the management of time in major projects: dynamic time modelling (2nd ed.) & $\mathrm{CIOB}$ & $£ 54$ \\
\hline Handbook of soil mix walls & N Huybrechts and N Denies & $£ 180$ \\
\hline Health and safety pocket book (2nd ed.) & G Hunt & f24 \\
\hline $\begin{array}{l}\text { How to write bids that win business: a guide to improving your bidding success rate and winning more } \\
\text { tenders }\end{array}$ & D Molian and others & $£ 45$ \\
\hline Hydropower & P Breeze & f39 \\
\hline Initial professional development for civil engineers ( 2 nd ed.) & P Waterhouse & $\mathbf{f 3 0}$ \\
\hline Innovation in wind turbine design ( 2 nd ed.) & P Jamieson & $£ 78$ \\
\hline Leading and managing professional services firms in the infrastructure sector & T Ellis & 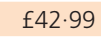 \\
\hline Making cities smarter: designing interactive urban applications & M Tomitsch & $£ 32$ \\
\hline Metric handbook: planning and design data (6th ed.) & P Buxton & f39. \\
\hline Natural capital: theory and practice of mapping ecosystem services & P Kareiva et al. & $£ 43$ \\
\hline New code of estimating practice (8th ed.) & $\mathrm{CIOB}$ & f64 \\
\hline Offshore wind energy technology & O Anaya-Lara et al. & f93. \\
\hline $\begin{array}{l}\text { Operational readiness guide: a guide to ensuring long term effectiveness in the design and construction } \\
\text { process }\end{array}$ & BIFM & f29. \\
\hline Plain language BIM & I Miskimmin & $f 21$. \\
\hline Port designer's handbook (4th ed.) & C Thoresen & $\mathbf{f 1 2 0 . 0 0}$ \\
\hline Professional negligence in construction ( 2 nd ed.) & B Patten and H Saunders & f170. \\
\hline Replenish: the virtuous cycle of water and prosperity & S Postel & f16. \\
\hline Sentinels of the sea: a miscellany of lighthouses past & R Grant & f13. \\
\hline Sequential excavation for tunnels and shafts & C Felice & f95. \\
\hline Smart water technologies and techniques & D Owen & £89. \\
\hline Steel connection analysis & P Rugarli & f99. \\
\hline Structural health monitoring of large civil engineering structures & H Chen & f84 \\
\hline Sustainable building design: principles and practice & M Keeping and D Shiers & f55 \\
\hline Sustainable desalination handbook: plant selection, design and implementation & G Gude & f138 \\
\hline The bridge: how the Roeblings connected Brooklyn to New York & P Tomasi & f13. \\
\hline $\begin{array}{l}\text { The finite element method: fundamentals and applications in civil, hydraulic, mechanical and } \\
\text { aeronautical engineering }\end{array}$ & B Zhu & f135 \\
\hline Underground spaces unveiled: planning and creating the cities of the future & H Admiraal and A Cornaro & f70. \\
\hline Wheelchair housing design guide (3rd ed.) & M Horn & f35. \\
\hline Will it stand up? A professional engineer's view of the creation of the London 2012 Olympic stadium & D Mason & f16. \\
\hline
\end{tabular}

